\title{
Food Blogger Review on Instagram as an Alternative for Helping Consumer Purchase Decision
}

\author{
G.T Puspita \\ Universitas Pendidikan Indonesia \\ Bandung, Indonesia
}

\author{
H.Hendrayati \\ Universitas Pendidikan Indonesia \\ Bandung, Indonesia
}

\begin{abstract}
For those who love cuisine, they certainly will be familiar to the existence of food bloggers. Food Blogger as social media marketing especially in Instagram, used to provide reviews about culinary products. The existence of food bloggers is believed to help consumers to choose which place that suits their needs. This research is a quantitative research that aims to determine whether there is partial influence between foods blogger reviews on Instagram toward consumer purchasing decisions of culinary in the city of Bandung and to find out whether there is a simultaneous influence between foods blogger reviews on Instagram toward consumer purchasing decisions regarding culinary in the city Bandung. The method used is descriptive method. The sampling technique used is nonprobability sampling with incidental sampling type. The data collection is done by spreading questionnaires to 100 Instagram user communities who follow food blogger and live in Bandung city or frequently having a culinary tour in Bandung city. The data analysis technique used is multiple linear regression analysis. Based on $t$ test results, context and collaboration variables significantly influence consumer purchasing decisions regarding culinary in the city of Bandung. Then, $F$ test results show that the value of $F$ arithmetic of 42,219 with a significance level of 0.000 . This means that the reviews of food bloggers on Instagram have a significant influence on consumer purchasing decisions toward culinary in the city of Bandung.
\end{abstract}

Keywords—Food blogger; purchasing decision

\section{INTRODUCTION (HEADING l)}

Along with the development of the global world, competition of the digital era is increasingly tight and opens the opportunities yet presents new challenges in the business world. The emergence of global digital era presents more rapid and complex technology and information. This phenomenon evolves in harmony with the advances of information technology.

Currently, almost all business activities are integrated with information technology tools. The adaptation of information technology is not only applied at the internal level of business organization, but also at the external level; they are in the context of marketing communications and community relations. In the past times, only large businesses can go international, now through the internet almost all business categories can be accessed by everyone in the world. This happens because information technology has made all the elements in this world connected and integrated with each other. At this level, business activity seems to be "folded" by the sophistication of information and communication technology [1].

One way to generate consistency of a stronger message on millennial generation is through social media with third-party intermediaries. A third party here means a person or group of people who are rated as influencers. They are people who have pretty much followers in social media and they have a strong influence on their followers such artists, selebgram, blogger, you tuber, and so forth. The influencers are widely used by business people to support in the introduction of sales product. One influencer that will be discussed in this article is a blogger in the field of culinary or often called "food blogger".

For culinary connoisseurs, certainly they will be familiar to the existence of food bloggers as social media marketing, especially in Instagram. Food Blogger is accustomed to provide reviews about culinary products from street snack food, homemade food, canteen or small food stalls, indie cafes to restaurants located in star hotels. The existence of mushrooming food blogger was also ogled by the business people in the culinary field.

The impact of digital development is more happening at the business level rather than on its food processing business. As a result, the utilization of social media such as Instagram is so very popular [2]. The same is revealed by Steven Kim, the founder of the Qraved culinary directory site. A Place to eat which still use a standard campaign according to him will not last long. He said that many place to eat which do not know how to sell their food through media social. To rate those places which do not take the advantage of digital development well would probably go bankrupt [2]

In the city of Bandung itself, various types of culinary can be obtained in every corner of the city. There is almost no place in Bandung that no one sells food. Therefore, the city of Bandung is often also referred as "culinary paradise". This means, competition in the culinary area of Bandung is getting increasingly stricter. If culinary business people in Bandung cannot make a good marketing system, this will generate fear that their culinary business will not be able to compete. Here 
are the top 10 Instagram food blogger accounts in Bandung with the most followers, namely: @kulinerbandung, @duniakulinerbdg,@caferestodiary,@makanpakereceh, @foodnotestories,@bandungeatery, @infobandungkuliner, @bdgsociety,@lets.go.eat, and @kulinerbdg.

The existence of food blogger is believed to be a tool for consumers to choose which restaurant suits their needs. Based on the description above, this article will discuss how far the effectiveness of food blogger reviews in Instagram of consumer purchase decision alternatives.

Someone who shares and writes about food in a blog is known as a food blogger. In addition, food bloggers are not only use blogs as their media to share but also social media such as Instagram which is a social media to share photos online, which later it becomes one of the food blogger tools to share [3]. Food bloggers are made by someone who is interested in cooking or trying new foods either by cooking themselves or visiting a place that has a variety of different and unique foods [3]. Food bloggers are widely known by the public and have a large followers so they have the ability to influence others or as influencers.

Social media marketing focuses on social media platforms to market products or services [4]. Social media marketing provides a way for companies to reach new customers and engage with the existing customers. There are $4 \mathrm{C}$ in the use of social media such as Context, Communication, Collaboration, and Connection [5]. 4C can be an indicator for a food blogger to make a good and interesting review . The explanation of $4 \mathrm{C}$ is as follows:

1) Context, Talking about how we form a story or message (information) as the form of a message itself, the use of the language as well as the content of the message.

2) Communication, Talking about how to share stories or messages (information) as well as about what we hear, responds and grows in various ways which make users feel comfortable and messages delivered properly.

3) Collaboration, talking about how to work together to make things better.

4) Connection, Talking about how to maintain relationships to be well constructed.

Promotion through food blogger on Instagram social media in the eyes of respondents as a whole is in the position of good category [3]. This shows that promotion through food blogger on Instagram social media can be a tool which can be used by restaurant business actors in doing business promotion. Students' interest in buying stuff in the city of Bandung as a whole is in good category [3]. This shows that students in Bandung City wish to make a purchase based on the influence of food blogger account on Instagram social media.

In addition, a research shows that attitudes toward advertisement consist of personal relevance, interactivity, message and brand familiarity which has simultaneous significant influence on consumer purchasing decisions at cafes and restaurants in Bandung for $39.3 \%$ [2]. Partially, all attitudes variable to advertisement have significant influence to consumer purchasing decision at café and restaurant in Bandung city. Personal relevance variable is the most dominant variable influencing consumer purchase decision at café and restaurant in Bandung that is equal to $17.1 \%$.

Lombo \& Maria (2014) [6] in their research entitled "The Impact of Celebrity Endorsement to Youth Consumer Purchase Decision on Adidas Apparel Product" mention there is a significant influence on attraction and expertise of celebrity endorsement on teenage consumers purchasing decisions. Teenage consumers are strongly influenced by the physical appearance of celebrity endorsement in making purchasing decisions. The Endorser here are accounts with many followers, one of them is a food blogger.

Meanwhile a research entitled "The Impact of Online Costumer Review and Celebrity Endorsement on Purchase Intention" mentions that there is a significant influence of online customer reviews and celebrity endorsements for the intention of purchasing customers simultaneously. Researchers suggest paying attention to Celebrity endorsement, as Celebrity endorsement has a strong effect on consumer memory and learning approaches as well.

The last one was Agustina (2014) [7] with their research "Celebrity Endorser Analysis and Psychological Factors against Short Message Application Decisions on Smartphone" said that the better use of Celebrity Endorser in promotion, the higher the number of mobile messenger or Line application users.

Of all the above studies that took the theme on Celebrity endorsement has relatively similar results although the variables vary. Endorsement by influencers is very effective in generating a consistency stronger message and the impact of its larger specialized sales in this millennial generation. An influencer is not just celebrities or artists, anyone can be influencers such as programming, blogger, you tuber, and so forth. One influencer that will be discussed in this article is a blogger in the field of culinary or often called "food blogger". Based on the results of previous research, it can be seen that a food blogger is one form of Celebrity Endorsement which puts himself as social media marketing and has a big influence in consumer purchase decisions.

\section{METHOD}

This research is a quantitative research. Research method used by the writer in this research is descriptive method. The purpose of descriptive research is to obtain informations about a condition or a condition that is currently happening and see the relationship between variables that exist. The research also uses a causal method. In this research, the independent variable is promotion through food blogger on Instagram social media and the dependent variable is the buying interest. The hypothesis proposed and will be verified in this research are:

Ho $=$ Food blogger reviews as social media marketing simultaneously has no significant effect on consumer purchasing decisions.

$\mathrm{Ha}=$ Food blogger reviews as social media marketing simultaneously has significant effect on consumer purchasing decisions. 
The instrument scale used in this research is Likert scale. Likert scale is used to measure the attitude, opinion, and perception of a person or group of people about social phenomena [8]. With Likert scale, the measured variables are translated into sub variable or variable. indicator. Then the indicator is used as a starting point to arrange the items of the instrument that can be a statement or question.

In this research, the targeted population is the user community of Instagram who follow one or several 10 big food blogger in Bandung and live in the city of Bandung or often have a culinary tour in the city of Bandung. Since the population is still in the approximate size with an uncertain amount, the researcher uses the determination of population by the formula [9]. The result of the calculation using Wibisono's formula shows the result that the minimum sample which should be used is 96,04 so the writer rounded the number of samples to 100 respondents. Sampling Techniques in this research, the researcher using Accidental Sampling, the sampling technique by chance found by the researcher who is considered fit with the characteristics that have been determined.

To support the analysis in this research, the data used in the research are primary data in the form of questionnaires distribution. Meanwhile, the secondary data are books, literature, journals, scientific works or past research and relevant websites on the internet.

\section{TABLE 1. VARIABLE OPERATIONAL}

\begin{tabular}{|l|l|l|}
\hline Variable & Sub Variable / Indicator & Item No \\
\hline \multirow{4}{*}{$\begin{array}{l}\text { Food Blogger Review As } \\
\text { Social Media Marketing (X) }\end{array}$} & Context (X1) & $1,2,3,4,5$ \\
\cline { 2 - 3 } & Communication (X2) & $6,7,8,9,10,11$ \\
\cline { 2 - 3 } & Collaboration (X3) & $12,13,14,15,16$ \\
\cline { 2 - 3 } & Connection (X4) & 17,18 \\
\hline \multirow{5}{*}{ Purchase Decision (Y) } & Problem Introduction & 19,20 \\
\cline { 2 - 3 } & Searching Information & $21,22,23$ \\
\cline { 2 - 3 } & Alternative Evaluation & 24,25 \\
\cline { 2 - 3 } & Purchase Decision Making & $26,27,28$ \\
\cline { 2 - 3 } & Post Purchase Behavior & 29,30 \\
\hline
\end{tabular}

\section{RESULT}

Based on the characteristics of respondents in this research, it can be seen that from 100 respondents, 32\% of respondents are male or 32 people and $68 \%$ of respondents are female or 68 people. This information shows that the respondents in this study were dominated by women. In addition, based on other characteristics, it can be seen that from 100 respondents, $70 \%$ are between 21-27 years old, 13\% are between 28-35 years old, $9 \%$ are over 35 years old and $8 \%$ are under 21 years old. This information indicates that the respondents in this study were dominated by people aged 21-27 years.
Validity test has been done to show the level of validity and questionnaire in this research. From the result of validity test of each variable by using SPSS 20 toward 100 respondents can be concluded that all item of statement have $r$ value count $>\mathrm{r}$ table and $\mathrm{p}$-value significance less than 0.05 . So that all statement items can be used in this research (valid).

Reliability test has been done to show the level of trust or questionnaire reliability in this research. From the results of reliability test of all variables, obtained Cronbach Alpha values of all variables of this research shows greater than the value of 0.6 then the answers of the respondents of the research variables are reliable, so it can be used for further research.

The data normality test in the research is seen using the Kolmogrov-Smirnov method. Result of normality test by using SPSS 20 obtained Sig. value 0.190 is greater than 0.05 so it can be stated that the data is normally distributed.

Heteroskedacity test in this research is done by looking at the scatterplot graphic. The results of the scatterplot graphical test, the researcher interprets that the points spread between below 0 to above 0 on the $\mathrm{Y}$ axis. Therefore it can be concluded that the independent variable does not occur heteroscedasticity.

A good regression model should not be correlated between independent variables. To detect the presence or absence of multi-co linearity in the model, see the tolerance and variance inflation factor (VIF). The result of multi-co linearity test using SPSS 20 obtained the tolerance value of all variables greater than 0.10 and the VIF value of all variables is smaller than 10. So, it can be concluded that there is no multi-co linearity among independent variables in the regression model.

\section{A. The results of multiple linear regression analysis}

Multiple regression test in this research is intended to see how the influence of context, communication, collaboration and connection to consumer purchasing decisions. By using multiple linear regression method obtained result as follows:

\section{TABLE 2. COEFFICIENTS}

\begin{tabular}{|c|c|c|c|c|c|c|}
\hline \multirow{2}{*}{\multicolumn{2}{|c|}{ Model }} & \multicolumn{2}{|c|}{$\begin{array}{l}\text { Unstandardized } \\
\text { Coefficients }\end{array}$} & \multirow{2}{*}{$\begin{array}{l}\begin{array}{l}\text { Standardized } \\
\text { Coefficients }\end{array} \\
\text { Beta }\end{array}$} & \multirow{2}{*}{$\mathbf{T}$} & \multirow{2}{*}{ Sig. } \\
\hline & & B & $\begin{array}{l}\text { Std. } \\
\text { Error }\end{array}$ & & & \\
\hline \multirow{5}{*}{1} & (Constant) & 7.009 & 2.570 & & 2.727 & 0.008 \\
\hline & Context & 1 & 0.187 & 0.394 & 4.914 & 0.000 \\
\hline & $\begin{array}{l}\text { Communicati } \\
\text { on }\end{array}$ & 0.200 & 0.126 & 0.126 & 1.457 & 0.149 \\
\hline & Collaboration & 0.624 & 0.218 & 0.298 & 2.867 & 0.005 \\
\hline & Connection & 0.588 & 0.333 & 0.142 & 1.768 & 0.080 \\
\hline
\end{tabular}

Based on the results of the table analysis above, itcan be explained through the regression model as follows:

$\mathrm{Y}=7.009+0.921 \mathrm{X} 1+0.200 \mathrm{X} 2+0.624 \mathrm{X} 3+0.588 \mathrm{X} 4$

From the regression equation can be explained as follows: 
b. Based on the result of $t$ test (partial) on regression model,

Constants $=7.009$. This means that if context variables, communications, collaborations and connections are equal to zero, then consumer purchase decision variables have value 7.009. The context coefficient $=0.921$. This means that if the context variable has increased by 1 unit while other variables are considered constant, then the dependent variable, that is consumer purchase decision will experience an increase of 0.921 . Communication coefficient $=0.200$. This means if the communication variable has increased by 1 unit while other variables are considered constant, then the dependent variable is consumer purchase decision will experience increase of 0200. Coefficient of collaboration $=0.624$. This means if the variables of collaboration increased by 1 unit while other variables are considered constant, then the dependent variable that is consumer purchasing decisions will experience an increase of 0.624 . Connection coefficient $=0.588$. This means if the connection variable has increased by 1 unit while other variables are considered constant, then the dependent variable that is the consumer purchasing decisions will increase by 0.588 .

\section{B. Coefficient determination test results (R2)}

The value of the coefficient of determination shown by the value of $\mathrm{R}^{2}$ of the regression model is used to determine the variability of the dependent variable which can be explained by the independent variables. Based on the analysis results obtained the following results:

TABLE 3. MODEL SUMMARY

\begin{tabular}{|l|l|l|l|l|}
\hline Model & $\mathbf{R}$ & $\begin{array}{l}\mathbf{R} \\
\text { Square }\end{array}$ & $\begin{array}{l}\text { Adjusted R } \\
\text { Square }\end{array}$ & $\begin{array}{l}\text { Std. Error of } \\
\text { the Estimate }\end{array}$ \\
\hline 1 & $0.800^{\mathrm{a}}$ & 0.640 & 0.625 & 3.185 \\
\hline
\end{tabular}

Based on the above table shows that the value of $\mathrm{R}$ square of 0.640 which means that the variability of consumer purchase decision variables that can be explained by context, communication, collaboration and connection variables by $64 \%$. Meanwhile, the rest of $36 \%$ is explained by other factors which are not included in this research.

\section{C. $\quad$ Test result $t$ (partial)}

$\mathrm{T}$ test is conducted to test level significance of the independent influence variables to the dependent variable partially. Level of significance used is $5 \%$. Based on the analysis results obtained the following results in Table 2 the partial test results is as follows:

a. Based on the results of $t$ test (partial) on the regression model, obtained t count value of 4.914 and significance value of context variable of $0.000<0.05$ (5\% significance level). It can be concluded that partially context variables significantly influence consumer purchasing decisions. obtained $t$ value counted 1.457 and value of significance of communication variable equal to $0149>0.05(5 \%$ significance level). This means that it can be concluded that partially communication variables have no significant effect on consumer purchasing decisions.

c. Based on the result of t test (partial) on regression model, obtained $t$ value counted 2.867 and value of significance of collaboration variable equal to $0.005<0.05(5 \%$ significance level). It can be concluded that partially collaboration variables significantly influence consumer purchasing decisions.

d. Based on the result of t test (partial) in regression model, obtained t value counted 1.768 and significance value of connection variable equal to $0.080>0.05 \quad(5 \%$ significance level). It can be concluded that partially connection variables have no significant effect on consumer purchasing decisions.

\section{Test result f}

The $\mathrm{F}$ test is to show whether the independent variables included in the model have a mutual influence on the dependent variable. Testing is done with a significance level of $5 \%$ or 0.05 . Based on the analysis results obtained the following results:

TABLE 4. ANOVA

\begin{tabular}{|l|l|l|l|l|l|l|}
\hline \multicolumn{2}{|l|}{ Model } & $\begin{array}{l}\text { Sum of } \\
\text { Squares }\end{array}$ & df & $\begin{array}{l}\text { Mean } \\
\text { Square }\end{array}$ & F & Sig. \\
\hline \multirow{2}{*}{1} & Regression & 1713.067 & 4 & 428.267 & 42.219 & $0.000^{\mathrm{b}}$ \\
\cline { 2 - 7 } & Residual & 963.683 & 95 & 10.144 & & \\
\cline { 2 - 7 } & Total & 2676.750 & 99 & & & \\
\hline
\end{tabular}

Based on the table above, it can be obtained the value of $F$ arithmetic of 42.219 with a significance level of 0.000 . This shows that the significance level of $\mathrm{F}$ count is less than the significance level of 0.05 . This means that context, communication, collaboration and connection variables together have a significant influence on consumer purchasing decisions.

\section{CONCLUSION}

Based on the research result that has been done about the influence of food blogger reviews as social media marketing to alternative purchasing decisions consumer in Bandung, it can be concluded that the variable context and collaborations partially has significant effect on consumer purchasing decisions. The communication and connections variable partially has no significant effect on consumer purchasing decision. However, food blogger reviews on Instagram social media which is consisting of context, communication, collaboration, and connection affect the alternative consumer 
blogger admin account on Instagram social media when it needs to answer a question, and delivering message by the food blogger account on Instagram social media on the content which is displayed in more complete version.

\section{REFERENCES}

[1] Suwatno, S. 2017. Komunikasi bisnis yang adaptif. Retrieved on June 20, 2018 from http://suwatno.staf.upi.edu/2017/05/komunikasi-bisnisyang-adaptif.html.

[2] Amri, B. A. C. 2016. Pengaruh iklan melalui food blogger pada media sosial instagramterhadap keputusan pembelian konsumen. Telkom University: Bandung

[3] Syahbani, M. F., \& Widodo, A. 2017. Food blogger instagram: Promotion through social media. Bandung: Telkom University.

[4] Felix, R., Rauschnabel, P. A. \& Hinsch, C. 2016. Elements of strategic social media marketing: a holistic framework. Journal of Business Research, 1-9.

[5] Hauer, C. 2010. in Solis, B. Engage: The complete guide for brands and business to build cultivate and measure success on the web (263). New Jersey: John Wiley \& Sons.

[6] Lombo, V. E. P. \& Maria V.J. T. 2014. The impact of celebrity endorsement to youth consumer purchase decision on Adidas apparel product. Manado: Universitas Sam Ratulangi.

[7] Agustina, A. 2014. Analisis celebrity endorser dan faktor psikologis terhadap keputusan penggunaan aplikasi pesan singkat pada smartphone. Bandung : Universitas Pendidikan Indonesia.

[8] Sugiyono, S. 2011. Metode penelitian kuantitatif, kualitatif dan R\&D. Bandung: Afabeta

[9] Wibisono, D. 2003. Riset bisnis. Jakarta: PT. Gramedia Pustaka Utama. of food blogger on Instagram social media. Based on the responses from consumers, the improvement can be done by increasing the posting content intensity owned by the food blogger account on Instagram social media, increasing of 